Gut, 1978, 19, 715-723

\title{
Transport of large breakdown products of dietary protein through the gut wall
}

\author{
W. A. HEMMINGS AND E. W. WILLIAMS \\ From the Agricultural Research Council Immunology Group, Zoology Department, University College of \\ North Wales, Bangor
}

SUMMARY Ferritin or tritium labelled immunoglobulin G may, by electron microscopy, be demonstrated entering, within, and leaving the epithelial cells. Quantitative studies using various proteins labelled with radioiodine show that large amounts of protein bound radioactivity may be demonstrated in the tissues after feeding the labelled protein to adult rats by stomach tube. The molecular size of this material as determined by sugar gradient ultracentrifugation of tissue extracts ranges when IgG is fed from 50000-20000 Daltons. The material retains its ability to react as antigen with antisera specific to the original molecule: precipitation reactions may be obtained in gels and quantitative studies show that considerable amounts of the protein-bound radioactivity are still specifically precipitable. Such studies have been carried out with $\alpha$-gliadin as well as bovine IgG. At 100 days old rats may absorb as much as $40 \%$ of a dose of bovine IgG in the form of these large molecular breakdown products.

It has been long recognised that in the suckling rat and mouse there is a massive transport of immunoglobulin from the milk across the gut into the circulation. This transport is selective, in that it favours the absorption of homologous IgG, and it ceases abruptly at $\mathbf{1 5}$ days in the mouse, or $\mathbf{2 1}$ days in the rat, at the 'cut-off'. The process is summarised by Brambell's reviews $(1958,1970)$.

More recently, it has been shown that a second process of absorption occurs in the suckling, which is ileal rather than duodenal, and which results in the absorption of part molecules rather than native ones. This was first demonstrated for ferritin (Hemmings, 1975c) and IgG (Hemmings and Wood, 1975a). Approximately $25 \%$ of a dose of bovine IgG is present in the carcase in the form of large molecular breakdown products a few hours after feeding (Hemmings and Wood, 1975b). This has been independently confirmed (Morris and Morris, 1976), although the latter report finds a rather lower proportion of the dose in the carcase $(15 \%)$. The discrepancy may be due to differences of experimental procedure.

The important fact, however, is that this ileal absorption of degraded protein is not subject to the 'cut-off' but continues unabated into mature life in the rat, and indeed increases steadily to a maxi-

Received for publication 7 March 1978 mum at about 100 days of age, when the animal is fully mature (Hemmings et al., 1977).

Ferritin has been demonstrated passing through the enterocytes of the suckling rat in the ileal as well as the duodenal regions (Hemmings and Williams, 1976a) and tritium labelled bovine IgG has been localised within adult ileal epithelial cells by direct deposition autoradiography at the electron microscopic level (Hemmings and Williams 1976b), so that these preliminary studies suggest that these large proteins, or fragments of them sufficient in size to retain the markers, pass freely into the cytoplasm of the absorptive cells, and thence into the intercellular space and on into the circulation and the lymphatics. Further studies were undertaken to confirm these findings and to investigate further the mechanisms by which such large molecules pass through the cell (Williams, 1978). An important consideration is whether the breakdown products found in the tissues represent large fragments of the original molecules or whether much smaller breakdown products, such as small peptides, could have become linked to native protein carriers in the circulation and tissues. Immunological tests have therefore been undertaken to see to what extent the breakdown products retain the antigenicity of the original molecule both when $\alpha$. gliadin is fed and bovine IgG (Hemmings et al., 1976). Considerable amounts of the protein-bound 
radioactivity of the tissues retain the ability to precipitate with antisera specific to those molecules.

In the studies to be reported here, further quantitative experiments have been undertaken, to determine the effect of feeding a variety of iodinelabelled proteins in doses in the milligram range under normal physiological conditions. The proteins include IgG, wheat gliadins because of their interest in coeliac disease, and haemoglobin because of its potential as a treatment for iron deficiency.

\section{Methods}

\section{ANIMALS}

Albino rats of a Wistar strain which has been maintained in this laboratory for more than 25 years were used. Sucklings were taken straight from their mothers and fed by means of a fine-drawn polyethylene catheter attached to an Agla syringe. Adults were anaesthetised lightly with ether, and fed by a taper-tipped $2 \mathrm{~mm}$ polyethylene catheter attached to a tuberculin syringe. Sucklings were fed $0.1 \mathrm{ml} 1 \%$ protein solution, adults volumes of up to $1.0 \mathrm{ml} 1 \%$ protein solution. At the end of the experimental period animals were killed by exposure to chloroform.

\section{NECROPSY}

At killing, heart blood was collected. Serum was separated, and precipitated with $1 \%$ tungstic acid solution, freshly prepared. Protein precipitate and supernatant were separated for counting. The alimentary canal was separated after dissection and the stomach counted separately. The small intestine was washed through with $30 \mathrm{ml}$ phosphate buffered saline pH 7.0 (PBS). The liver was removed, and the carcase of adults skinned, the skin being discarded. Intestine, liver, and carcase were macerated in a homogeniser in appropriate volumes of phosphate buffered saline and aliquots precipitated with $10 \%$ tungstic acid, precipitate and supernatant being counted separately. In some cases brain, spleen, and kidney were removed and treated separately also.

\section{PROTEINS}

Gliadin fractions were prepared by the method of Patey and Evans (1973). Bovine IgG was purchased (Armour). Proteins were trace-labelled by reaction with either ${ }^{131}$ I (IBS 30) or ${ }^{125}$ (IMS 30) purchased from the Radiochemical Centre, Amersham. The electrolytic method of iodination was employed (Rosa et al., 1964), $1 \mathrm{ml} 2 \%$ protein solution in PBS being reacted with usually $2 \mathrm{mCi}$ at $0.5 \mathrm{~mA}$ for 20 minutes, with sufficient carrier $\mathrm{NaI}$ added to give a level of iodination of 0.25 atom/molecule protein, at the efficiency achieved of approximately $50 \%$. Preparations were dialysed in the cold against several changes of phosphate buffered saline to remove unbound iodide.

\section{COUNTING}

Counting was carried out in twin-channel spectrometer scalers of Panax or Elscint manufacture, correction being made of the apparent ${ }^{125}$ I count for cross-talk due to ${ }^{131} \mathrm{I}$, where both isotopes were used together.

\section{PRECIPITIN TESTING}

Antisera to $\alpha$-gliadin raised in sheep, and to bovine IgG raised in rabbits, were titrated against their respective antigens to establish the optimal proportions equivalence. Tissue extracts were made by macerating and grinding portions, thereafter submitting the extract to centrifugation at $100000 \mathrm{~g}$ for 30 minutes to prepare the cytosol supernatant fraction. To aliquots of serum or cytosol, equivalent quantities of antigen and antibody were added, and the tests left in the refrigerator for 48 hours. The tubes were then centrifuged and the precipitate washed twice with cold phosphate buffered saline before counting.

Controls were carried out in the usual manner omitting one or other reagent. In addition, controls were made of non-specific attachment of tissue radioactivity to the serological precipitate by adding the alternative pair of reagents - thus the antibovine IgG system to samples from an experiment where gliadin had been fed. All controls were satisfactory.

SUCROSE- GRADIENT ULTRACENTRIFUGATION This was effected essentially by methods previously described (Hemmings and Jones, 1962; Hemmings, 1975a) using gradients from $5-40 \%$ sucrose in the Sw 50 rotor of a Spinco Model $\mathrm{L}$ ultracentrifuge. Tubes were typically fractionated into 25-30 fractions by means of a capillary siphon, at the end of the run, which was usually of 24 hours' duration at 50000 rpm. ${ }^{1}$

\section{Results}

Quantitative studies of transport of several proteins across gut of adult rat

Table 1 summarises the experiments undertaken in the quantitative studies, where labelled proteins were fed and the sera and other samples harvested after a lapse of time, for the most part eight hours. The serum concentrations, quoted as concentration quotients-that is, the ratio, specific activity of

${ }^{1}$ Fluorescein labelled markers of IgG, albumin, and hog stomach pepsin were incorporated in each run. 
Table 1 Serum concentration quotients $(C Q)^{*}$ of tungstic acid insoluble radioactivity after feeding various labelled proteins to adult rats

\begin{tabular}{|c|c|c|c|c|}
\hline Protein fed & No. & $\begin{array}{l}\text { Experimental } \\
\text { period }(h)\end{array}$ & $C Q$ & $\pm S E$ \\
\hline $\begin{array}{l}\text { Rat IgG } \\
\text { Bovine IgG } \\
\text { a-gliadin } \\
\beta \text {-gliadin } \\
\gamma \text {-gliadin } \\
\text { Porcine Hgb }\end{array}$ & $\begin{array}{l}5 \\
5 \\
6 \\
5 \\
6 \\
5\end{array}$ & $\begin{array}{r}8 \\
8 \\
24 \\
8 \\
8 \\
8\end{array}$ & $\begin{array}{l}0.000010 \\
0.000136 \\
0.000053 \\
0.000089 \\
0.000089 \\
0.000056\end{array}$ & $\begin{array}{l}0.000010 \\
0.000031 \\
0.0000053 \\
0.0000205 \\
0.0000105 \\
0.000018\end{array}$ \\
\hline
\end{tabular}

sample/specific activity of the solution fed-are seen to fall into a close group of values for a number of diverse proteins. The highest value, in fact, is bovine IgG, the lowest rat IgG. This is somewhat surprising, and a reversal of what is found in the suckling rat (Jones, 1972). Although the values are low in absolute terms, they still represent a considerable part of the dose fed-for example, taking a blood volume of $15 \mathrm{ml}$, the content of bovine IgG in this experiment represents $5 \%$ approximately of the amount fed.

However, a far greater part of the dose is to be found in the tissues. The distribution of the remaining radioactivity through the tissues in the case of the rat and bovine IgG feeding is shown in Table 2. The gut wash and stomach fractions represent the portion of the fed activity not absorbed: the remaining fractions are of tissues, and it can be seen that the largest amount is found in the proteinbound activity of the carcase, not surprisingly, since this is by weight the largest fraction. Significant amounts are seen in the washed gut tissue and in the liver. Carcases were skinned before maceration, so skin activity, which is not inconsiderable, does not appear in the balance.

It is clear from this table tha $i$ protein derivatives of the fed material are present in great quantity throughout the tissues, and that the carcase content of these derivatives represents a large part of the fed dose for both proteins.

Table 3 presents similar data where $\alpha$-gliadin has been fed, Table 4 does this for $\beta$, and Table 5 for $\gamma^{\prime}$-gliadin. The difference between these tables lies essentially in the duration of the experiment: the $a$-gliadin, 24 hour experiment, shows a lower proportion of the dose unabsorbed from the gut. When this is taken into account the results are very similar for all three gliadin components.

Table 6 gives the same type of data where porcine haemoglobin has been fed. This would appear to be more readily absorbed than the gliadins, but the essential details of the proportion present in the carcase as protein-bound activity are closely similar
Table 2 Percentage of fed dose found in various fractions after administration of ${ }^{131}$ I labelled bovine IgG and ${ }^{125}$ I labelled rat IgG to adult rats (means of five animals, $\pm S E$ )

\begin{tabular}{lclll}
\hline Fraction & \multicolumn{3}{c}{ Bovine IgG } & \multicolumn{3}{c}{ Rat IgG } \\
\hline Gut wash & 5.58 & 0.31 & 11.42 & 1.68 \\
Stomach & 27.4 & 8.3 & 29.0 & 17.5 \\
Gut & 2.77 & 0.36 & 1.66 & 0.48 \\
$\quad$ Protein bound & 1.59 & 0.19 & 2.56 & 0.58 \\
$\quad$ Non-protein & 0.96 & 0.18 & 0.48 & 0.057 \\
Liver & 0.56 & 0.26 & 0.76 & 0.092 \\
$\quad$ Protein-bound & & & \\
$\quad$ Non-protein & 43.7 & 7.98 & 34.1 & 5.84 \\
Carcase & 17.5 & 3.0 & 20.0 & 2.56 \\
$\quad$ Protein-bound & & \\
\hline
\end{tabular}

Table 3 Percentage of fed dose found in various fractions after administration of ${ }^{125}$ I labelled a-gliadin to adult rats (means of six animals)

\begin{tabular}{lcl}
\hline Sample & $\%$ dose & $\pm S E$ \\
\hline Stomach & 2.94 & 0.67 \\
Intestinal washing & 27.89 & 5.46 \\
Hind gut & 9.18 & 1.72 \\
Washed intestine & 2.98 & 0.57 \\
Carcase & & \\
Tungstic ppt & 46.34 & 6.91 \\
Tungstic super & 9.71 & 1.70 \\
Brain & 0.145 & 0.0199 \\
Blood (1 ml serum) & 0.135 & 0.017 \\
\hline
\end{tabular}

Table 4 Percentage of fed dose found in various fractions after administration of ${ }^{131}$ I labelled $\beta$-gliadin to adult rats (means of five animals)

\begin{tabular}{lcr}
\hline Sample & $\%$ dose & $\pm S E$ \\
\hline Stomach & 45.1 & 15.03 \\
Hind gut & 19.1 & 7.35 \\
Washing & 10.8 & 1.50 \\
Washed intestine & 4.3 & 1.25 \\
Carcase & & \\
Tungstic ppt & 12.3 & 3.79 \\
Tungstic super & 8.4 & 2.39 \\
\hline
\end{tabular}

Table 5 Percentage of dose in various fractions after administration of ${ }^{131}$ I labelled $\gamma$-gliadin to adult rats (means of six animals)

\begin{tabular}{lcc}
\hline Sample & $\%$ dose & $\pm S E$ \\
\hline Stomach & 55.3 & 8.31 \\
Hind gut & 12.3 & 5.01 \\
Washing & 7.3 & 2.17 \\
Washed intestine & 3.5 & 1.19 \\
Carcase & & \\
$\quad$ Tungstic ppt & 13.7 & 4.83 \\
Tungstic super & 7.4 & 2.52 \\
\hline
\end{tabular}

although the ratio of protein bound to supernatant activity of the carcase is here lower.

IMMUNOLOGICAL ASSAY OF PROTEIN-BOUND RADIOACTIVITY OF TISSUES AFTER FEEDING VARIOUS PROTEINS

A possibility that had to be considered at an early 
Table 6 Percentage of dose fed in various fractions after administration of ${ }^{125}$ I labelled porcine haemoglobin to adult rats (means of five animals)

\begin{tabular}{lcc}
\hline Sample & $\%$ of dose & $\pm S E$ \\
\hline Alimentary canal & 17.85 & 5.04 \\
Liver & 5.92 & 6.50 \\
Tungstic ppt & 4.74 & 1.84 \\
Tungstic super & & \\
Brain & 0.151 & 0.196 \\
$\quad$ Tungstic ppt & 0.326 & 0.476 \\
$\quad$ Tungstic super & & \\
Carcase & 24.82 & 9.89 \\
$\quad$ Tungstic ppt & 46.16 & 10.58 \\
Tungstic super & & \\
\hline
\end{tabular}

stage is that quite small polypeptide fragments of dietary protein may be bound to native carriers in the lymph and tissues, and so appear as tungstic acid insoluble material in the analysis. To investigate this possibility it was decided to look for derivatives of the original antigens, using immune sera specific to those antigens. Should it be possible to get antigen/antibody reactions in the tissues it would be fair evidence that very large fragments of the original molecule were present in the tissues, and, of course, such reactions could be measured.

Measured precipitation was carried out in experiments where labelled $\alpha$-gliadin or bovine IgG was fed, the tissue macerates and serum being put up with equivalent concentrations of unlabelled antigen and immune serum, in this case prepared in rabbits, so that the small amounts of labelled antigen were co-precipitated at equivalence. Appropriate controls were included. The results are given in Table 7 for $\alpha$ gliadin, and Table 8 for bovine IgG. In both cases the serum values are surprisingly low, which presumably reflects the fact that the breakdown products in serum contain much denatured material. In both cases the liver, spleen, and kidney content is high, when one remembers that these results are expressed as a percentage of the total activity of the tissues, including the tungstic acid soluble fraction. It therefore seems clear that these results confirm those obtained with the gel diffusion tests (Williams, 1978) in demonstrating that a considerable portion of the proteinbound activity of the tissues retains its antigenicity.

\section{ULTRACENTRIFUGAL EXAMINATION OF} TISSUES AFTER FEEDING OF BOVINE IgG

Adult rats were fed bovine IgG labelled with ${ }^{125}$ I, and serum, liver, spleen, kidney, and carcase samples taken for analysis. These were macerated and ground where appropriate, and centrifuged at $100000 \mathrm{~g}$ for half an hour to precipitate all organelles. The supernatant cytosol fraction was then layered on to sugar gradient tubes, which were centrifuged for prolonged times at $50000 \mathrm{rpm}$ to
Table 7 Percentage of total radioactivity present in tissues which is specifically precipitable with immune serum after feeding ${ }^{125}$ I labelled a-gliadin to five adult rats

\begin{tabular}{lcl}
\hline Sample & \% precipitated & $\pm S D$ \\
\hline Serum & $6 \cdot 0$ & $2 \cdot 6$ \\
Liver & $20 \cdot 2$ & $2 \cdot 6$ \\
Spleen & 12.0 & $5 \cdot 4$ \\
Kidney & 13.4 & 3.3 \\
\hline
\end{tabular}

Table 8 Percentage of total radioactivity present in tissues which is specifically precipitable with immune serum after feeding ${ }^{125}$ I labelled bovine $\mathrm{Ig} G$ to five adult rats

\begin{tabular}{lcc}
\hline Sample & \% precipitated & $\pm S D$ \\
\hline Serum & 6.74 & $2 \cdot 84$ \\
Liver & $11 \cdot 2$ & 6.4 \\
Spleen & 16.7 & $16 \cdot 2$ \\
Kidney & 15.0 & 12.8 \\
\hline
\end{tabular}

bring the 7S peak close to the bottom of the gradient. Figure 1 presents the profile of radioactivity of the preparation of bovine IgG fed. Figure 2 presents the profile of the serum of the experimental rats. It can be seen that there is a dramatic difference between these two profiles. In the serum the 7S peak is reduced to a minor spike, and the majority of the activity is now sedimenting at a value less than $3 \mathrm{~S}$, indicating the presence of a major BDP of the IgG.

In the liver (Fig. 3) the pattern is broken up into a number of smaller peaks ranging from $>5$ to $2 S$, indicating the presence of a variety of breakdown products of different mass. Similarly, in the spleen, a range of peaks from $<5 S$ to $2 S$ exists (Fig. 4) and again in the kidney the breakdown products are multiple in mass. In the kidney (Fig. 5) for the first time there is seen a major peak, that at the bottom of the tube, of mass greater than $7 \mathrm{~S}$.

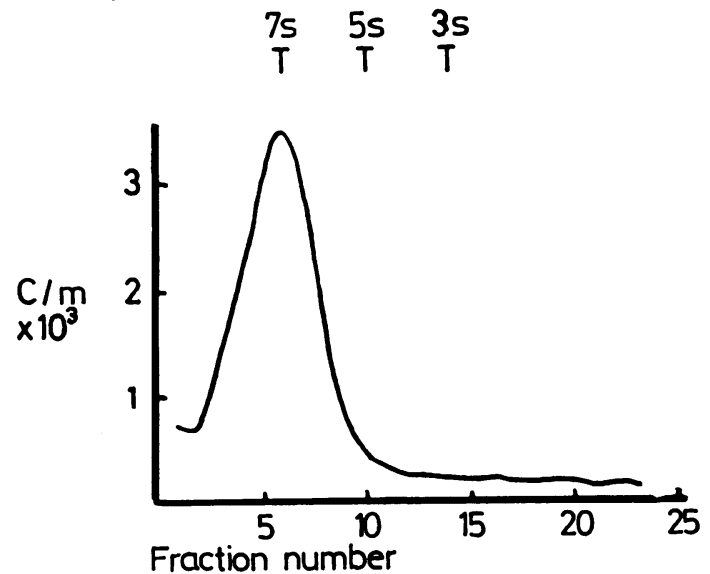

Fig. 1 Profile of radioactivity of sucrose gradient ultracentrifugation of labelled bovine IgG. 


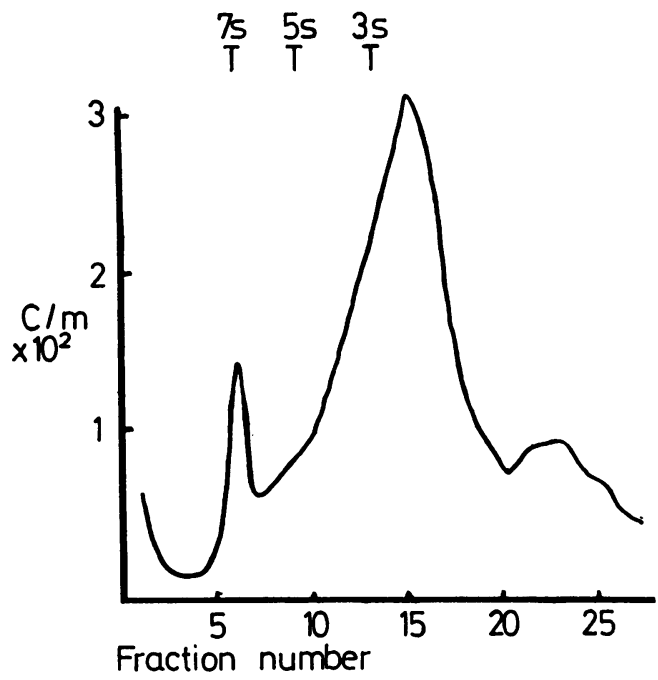

Fig. 2 Profile of serum of adult rats fed bovine IgG of Fig. 1.

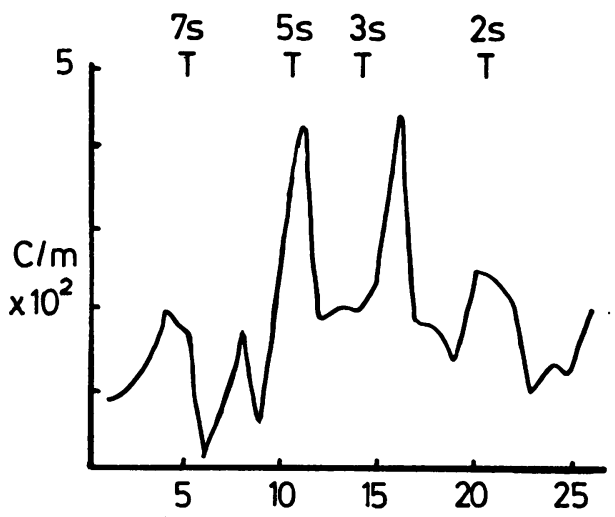

Fraction number

Fig. 3 Profile of liver cytosol of adult rats fed bovine IgG of Fig. 1 .

Thus, although the pattern in the serum is comparatively simple, the situation in each tissue chosen is complex, and differs in the distribution of mass range of the breakdown products, except perhaps for the $2 S$ component. Each of the three pictures presents a different pattern of breakdown products. The $5 \mathrm{~S}$ peak in liver may represent $7 \mathrm{~S}$ material derived from portal blood in process of degradation to the smaller entities: the $4 \mathrm{~S}$ peak of spleen is harder to explain as a derivative of the serum pattern. The kidney pattern is peculiarly complex, though it does contain approximate $3 \mathrm{~S}$ and $2 \mathrm{~S}$ peaks. It would be interesting to see the distribution of these molecules in polyacrylamide gel

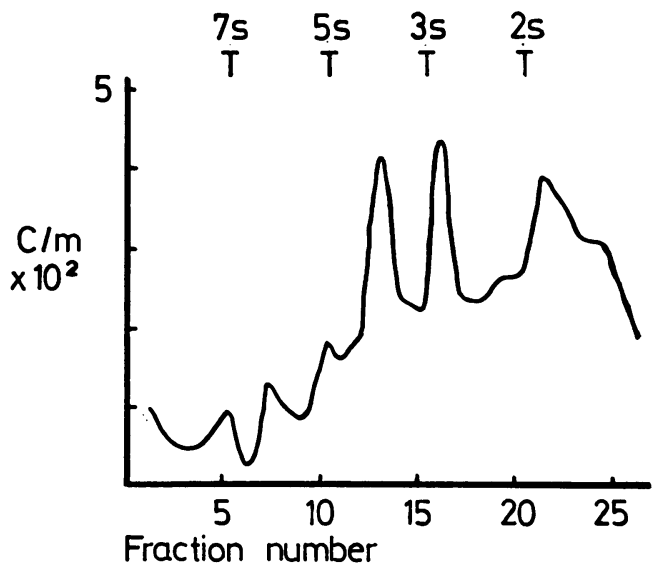

Fig. 4 Profile of spleen cytosol of adult rats fed bovine IgG of Fig. 1.

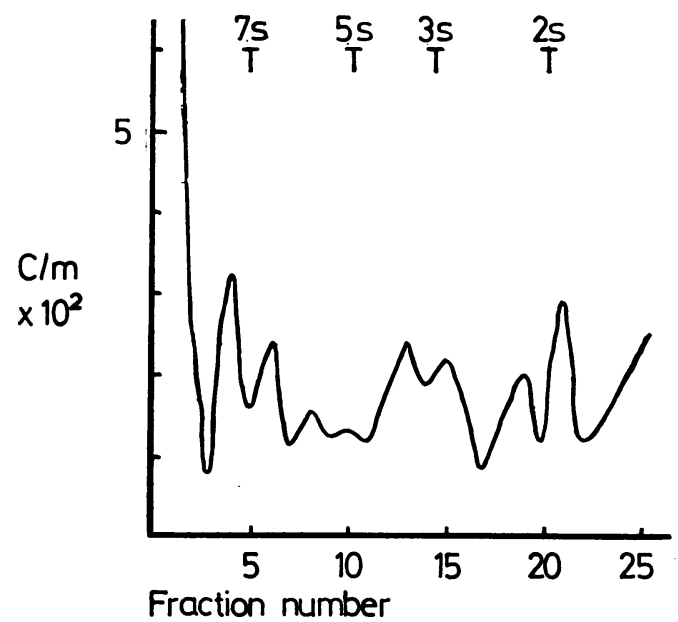

Fig. 5 Profile of kidney cytosol of adult rats fed bovine IgG of Fig. 1.

electrophoresis; a sufficiently sensitive scanning method is, however, not available, as it must be remembered that the specific activity of these samples is comparatively low. Attempts are planned to demonstrate antigenicity of the tissues in gel diffusion after the feeding of bovine IgG or other antigens. Simple Ouchterlony reactions, and immunoelectrophoresis of ferritin and bovine IgG in various tissues have, however, been carried out (Williams, 1978) with positive results.

\section{DECAY OF BREAKDOWN PRODUCTS IN} TISSUES

Twenty-five adult rats of approximately $300 \mathrm{~g}$ were fed $1 \mathrm{ml} 1 \%$ bovine IgG containing ${ }^{125}$ I labelled 
bovine IgG. They were divided into five groups, one group being killed at 24, 48, 96, 192 and 288 hours after the initial feed. Blood was collected, the intestine washed out, and liver and brain taken. The carcase was skinned and macerated. The protein bound activity of all samples was assayed, and the total content of that organ expressed as a percentage of the dose fed. The mean value of residual content of the tissues, and of $5 \mathrm{ml}$ serum, are shown as $\log / \log$ plots in Figs 6 and 7.

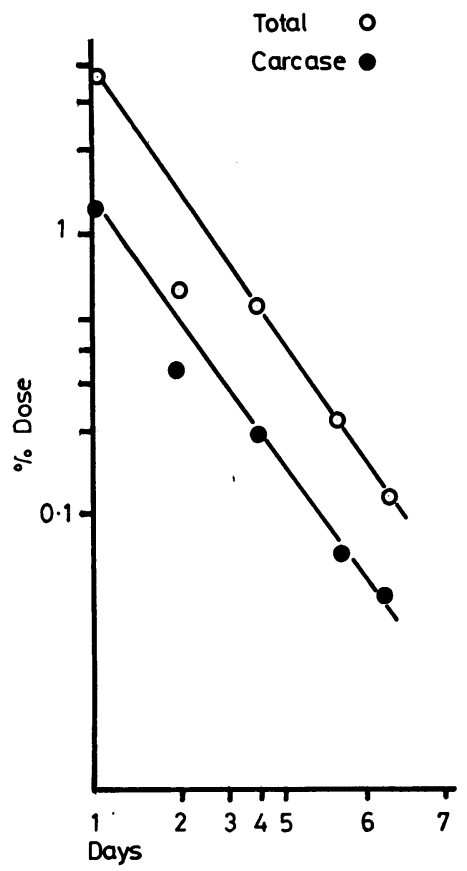

Fig. 6 Log/log plot of the percentage of the activity fed present in the carcase and in the sum of all fractions recovered, against time, after feeding bovine IgG labelled with ${ }^{125} I$ to adult rats.

It can be seen that the regression lines, fitted by eye, form a close family of lines. The total content and the carcase content fall off apparently in parallel, as might be expected, the range of the data being for the total activity from $4 \%$ on the first day to about $0.1 \%$ on the 12 th. Liver, and especially serum, values appear to fall faster than this: serum from $0.08 \%$ on the first day to $0.00009 \%$ on the 12 th. The brain, which is the subject of a separate communication (Hemmings, 1978), stands apart from the other tissues in having a much lower rate of decay: from $0.0001 \%$ on the first day to $0.00004 \%$ on the 12 th, to $39 \%$ only in the course of this experiment.

The picture is, overall, one of steady but not too fast processing of the foreign breakdown products in the tissues. We do not know from these radio-

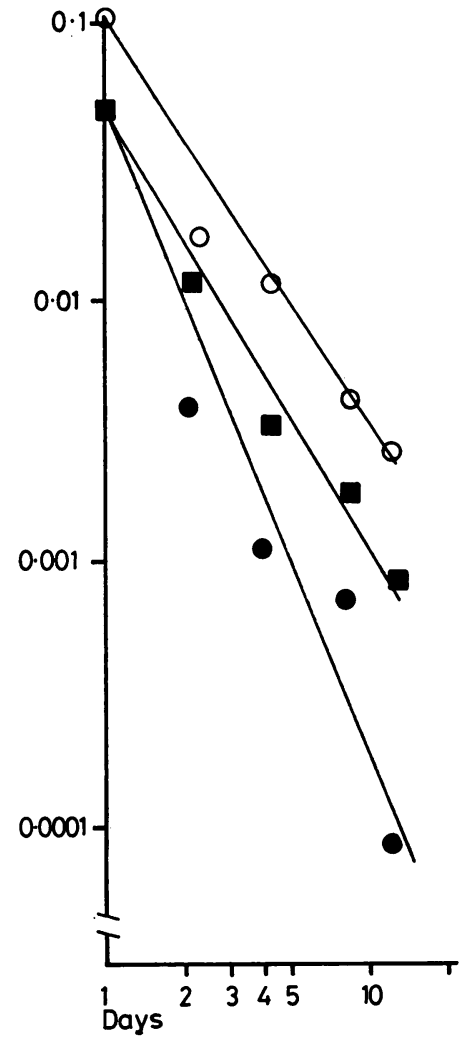

Fig. 7 Log/log plot of the percentage of the activity fed remaining in intestine $(\bigcirc)$, liver $(\square)$, and serum $(\bullet$, of adult rats fed bovine IgG labelled with ${ }^{125}$ I.

tracer data that the protein breakdown products are, in fact, being degraded at all: it could well be that part at least of the release of radioactivity from the tissues is due to uncoupling of the iodine from the protein, without degradation of the protein necessarily accompanying that event. It has been shown that deiodinase activity is potent in the small intestine, and that incoming labelled protein is there partially deiodinated (Jones, 1977). From the present data the decay in the washed intestine protein is no faster than that in the skeletal muscle, despite the known existence of the deiodinase system in the gut. Therefore this type of experiment remains to be repeated using other means of identifying the breakdown products. Such other means could well be an antigenic determination using specific antisera to the original molecule. Before this can be done, however, it must be determined to what extent breakdown products of various molecular size react with such antiserum, both in the direct and in blocking tests, and this is being studied at present. In the present work, the identification of 
the breakdown products depends on precipitation with tungstic acid, so that it may be taken that anything which appears as protein has molecular mass $>10000$. Therefore it is possible that much large polypeptide material, which should properly be included as breakdown products, is appearing in the balance sheet as 'supernatant'. This is a conservative failing. Whether such polypeptide material could have antigenic activity, perhaps as blocking or haptenic reagents, is the subject of other communications.

\section{Discussion}

Since the first decade of this century it has been known that small quantities of dietary protein pass the gut wall in immunologically reactive form. Thus Uhlenhuth (1900) demonstrated that rabbits fed on eggs produced circulating precipitins to egg protein. It is not part of the present paper to review this older literature, which is extensive. Some effort to do this is made elsewhere (Hemmings, 1977). But practical recognition of this fact is made by the increasing attention paid in medical practice to conditions of food sensitisation such as bovine milk enteropathy, especially of infants, and of course coeliac disease. In animal husbandry, at least, oral immunisation is used as a commonplace procedure (Porter and Allen, 1978).

But the present paper is intended to call attention to a much larger effect. Oral immunisation calls for the passage of marginally small amounts of intact antigen. The present effect deals with the passage of very much more substantial quantities of protein partially degraded by enzyme action during the passage through and from the gut. A large part retains its original antigenicity as is shown by Tables 7 and 8 . Still more is present in degraded form, but still as large protein entities. These perhaps remain immunogenic, and experiments are under way to investigate this.

This material is present in the cells in tissue throughout the body. Thus the sugar-gradient ultracentrifugation studies, invariably carried out on macerates of tissue preclarified by centrifugation of the macerate at $100000 \mathrm{~g}$ for 30 minutes to remove all organelles, were made on the cytoplasmic sol or cell sap fraction, and reveal the protein-bound radioactivity present typically in the form of large degradation products of the range of 50000-20000 Daltons in large amounts.

It is perhaps surprising to find the tissue cells throughout the body to be loaded with so much foreign protein of dietary origin. Its fate is to be degraded, almost certainly over a fairly protracted period: this aspect of the physiology of the process is also under investigation. This might be termed distributed digestion, occurring in all body cells rather than in the gut lumen. The process seems primitive, not surprising to find perhaps in coelenterates, but amazing in its occurrence in mammals. There seems to be little of advantage in it, compared with the classical view of intestinal digestive processes as they have been understood-for example, by Fisher (1954) - of complete degradation in the gut lumen to amino acids and small peptides before absorption by enterocytes which were considered to be impermeable to molecules of any greater size than these. It seems to be rational from the point of view of evolutionary theory that digestion should long have come to be a specialised function of the gastrointestinal tract. Yet we now see that approximately half of the protein used as examples in the present study are not so broken down: that the enterocytes freely permit their passage into the systemic circulation, and that these large breakdown products freely enter all tissue cells to lodge there. Therefore it must be argued that some predominant necessity of cell physiology precludes the setting up in evolution of such a protein-impermeable intestinal barrier as the classical theory requires.

Tentatively, it is put forward that there is a universal necessity for body cells to be 'permeable' to proteins of many types, and that there is a constant traffic of protein molecules into all body cells. This point seems to be forced upon one by the present study of dietary breakdown products, but it must surely be seen from a more fundamental point of view as applying to a much wider range of circulating proteins than merely dietary breakdown products. The regulation of this traffic of large molecules through cell membranes that also regulate ionic flow is, of course, one of the prime matters of current study in cell physiology, but, whereas entry of protein to the cell has been in the past considered to be restricted and rare, and a matter when it occurs of specific attachment to receptors and carriers in the membrane, it must now be seen as a much more general process, open to an almost indefinitely wide range of chemical configuration of breakdown products and characterising all body cells rather than a few specialised types.

A central problem in this thesis is the passage of large amounts of heterogeneous protein across cell membranes, both in the gut and elsewhere in the body. Electron microscopic studies of the intestinal epithelium help to demonstrate that this process is certainly going on actively, but do not serve to explain the mechanism by which it works. It is hardly possible at present to go deeply into this subject, but some preliminary studies have been made on the glycocalyx reactions of a cell type specialised in the 
transport of protein, the endodermal cell of the foetal rabbit yolk - sac splanchnopleur-which have been briefly reported elswhere (Hemmings 1975b). It would seem the glycocalyx of these cells attaches rabbit and bovine IgG by means of separate receptor proteins, forming various complexes of high sedimentation value and very low pI. A trivial moiety of the total glycocalyx material is involved in forming these particular complexes, and it is at least credible that the rest of the glycocalyx contains a wide range of reagents capable of attaching a great variety of protein configurations. The suggestion has been made that attachment to the glycocalyx is automatically followed by ingestion back into the cell, the glycocalyx-derived part of the complex serving perhaps as a 'key' for passage through the cell membrane. The glycocalyx may form a sort of conveyor belt system, secreted on the surface of the microvilli and reabsorbed pinocctotically at the base between microvilli, making a conveyor belt of material avid to attach protein from the ambient medium. Although this mechanism is obviously highly developed in the endoderm cell, which is specialised for the absorption of protein, it may exist to some degree in all tissue cells, so that a 'patrol' of glycocalyx may form a fundamental cell mechanism by which protein is ingested into the cell.

A further large topic is the part played in absorption by prior immunisation. It is clear that native molecules do serve as antigens by the oral route, and antibodies, typically $\operatorname{IgA}$ in the secretions, are readily produced by oral immunisation (Bazin et al., 1973). But it is probable that more and different antibodies will be formed to the breakdown products of habitual food stuff. Such antibody formation does seem to influence the digestion and absorption of subsequent doses of the antigen. Thus, working with albumin, two groups of workers have shown a depression of uptake of native material in the immunised animal (André et al., 1974; Walker et al., 1975) and there is some suggestion that the presence of antigen leads to more complete intralumenal proteolysis. However, albu$\min$ is an unfortunate choice of antigen for this purpose because it is in any case largely broken down by peptic action. Preliminary work with bovine IgG in this laboratory does not show any large depression of the ingress of breakdown products to the carcase due to prior immunisation by the oral route (Wood, 1976, personal communication) and for the moment we must assume that the effect of such immunisation on the overall process is marginal. Further work is planned using ovalbumin and other species of IgG.

\section{References}

André, C., Lambert, R., Bazin, H., and Heremans, J. F. (1974). Interference of oral immunisation with intestinal absorption of heterologous albumin. European Journal of Immunology, 4, 701-704.

Bazin, H., André, C., and Heremans, J. F. (1973). Responses immunologiques induites par voie orale. Annales Immunologie (Inst. Pasteur), 124C, 253-272.

Brambell, F. W. R. (1958). The passive immunity of the young mammal. Biological Reviews, 33, 488-531.

Brambell, F. W. R. (1970). The transmission of passive immunity from mother to young. (Frontiers of Biology, Vol. 18.) North Holland: Amsterdam.

Fisher, R. B. (1954). Protein Metabolism. Methuen: London. Hemmings, W. A. (1975a). The reproducibility of sucrosegradient ultracentrifugation. IRCS Medical Science Library Compendium, 3, 437.

Hemmings, W. A. (1975b). Glycocalyx receptors and protein absorption by the endoderm cell. In Immunology of Reproduction, Proceedings of the 3rd Varna Symposium. Edited by K. Bratanov et al. (In press.)

Hemmings, W. A. (1975c). Degradation products in gut and carcase tissue after injecting labelled ferritin into the ileum of suckling rats. IRCS Medical Science, 3, 216.

Hemmings, W. A. (1977). The absorption of large breakdown products of dietary proteins into the body tissues including brain. In The Biological Basis of Schizophrenia. Edited by Gwynneth Hemmings. M.T.P. Press: Lancaster. (In press.)

Hemmings, W. A. (1978). The entry into the brain of large molecules derived from dietary protein. Proceedings of the Royal Society $B, 200,175-192$.

Hemmings, C., Hemmings, W. A., Patey, A. L., and Wood, C. (1977). The ingestion of dietary protein as large molecular mass degradation products in adult rats. Proceedings of the Royal Society. B. 198, 439-453.

Hemmings, C., Hemmings, W. A., and Williams, E. W. (1976). Immunological assay for antigen in tissues following feeding of labelled a-gliadin to suckling and adult rats. IRCS Medical Science, 4, 458.

Hemmings, W. A., and Jones, R. E. (1962). The occurrence of macroglobulin antibodies in maternal and foetal sera of rabbits as determined by gradient centrifugation. Proceedings of the Royal Society $B, 157,27-32$.

Hemmings, W. A., and Williams, E. W. (1976a). The attachment of IgG to cell components of transporting membranes. In Maternofoetal Transmission of Immunoglobulins, pp. 91-108. Edited by W. A. Hemmings. Cambridge University Press: London.

Hemmings, W. A., and Williams, E. W. (1976b). The use of direct deposition electron microscope autoradiography in studies of protein transport. Journal of Microscopy, 106, 131-143.

Hemmings, W. A., and Wood, C. (1975a). Selective protein absorption by the gut of the suckling rat following oral immunization: II The analysis of the uptake. IRCS Medical Science, 3, 342.

Hemmings, W. A., and Wood, C. (1975b). Selective protein absorption by the gut of the suckling rat following oral immunisation. III Ultracentrifugal analysis. IRCS Medical Science, 3, 436.

Jones, R. E. (1972). Intestinal absorption and degradation of rat and bovine gamma-globulins in the suckling rat. Biochimica et Biophysica Acta, 255, 530-538.

Jones, R. E. (1977). De-iodination of labelled protein during intestinal transmission in the suckling rat. Proceedings of the Royal Society B, 199, 279-290.

Morris, B., and Morris, R. (1976). Quantitative assessment of the transmission of labelled protein by the proximal 
and distal regions of the small intestine of young rats. Journal of Physiology, 255, 619-634.

Patey, A. L., and Evans, D. J. (1973). Large-scale preparation of gliadin proteins. Journal of the Science of Food and Agriculture, 24. 1229-1233.

Porter, P., and Allen, W. D. (1978). Antibody response in pigs and calves to antigens from the intestinal lumen and the efficiency of oral immunoprophylaxis against post-weaning enteric infection. In Antigen Absorption from the Gut. Edited by W. A. Hemmings. MTP Press: Lancaster.

Rosa, U., Scassellati, G. A., Pennisi, F., Riccioni, N., Giagnoni, P., and Giordani, R. (1964). Labelling of human fibrinogen with ${ }^{181}$ I by electrolytic iodination. Biochimica et Biophysica Acta, 86, 519-526.

Uhlenhuth, P. T. (1900). Neuer Beitrag zum spezifischen Nachweis von Eireiweiss auf biologischem Wege. Deutsche Medicinische Wochenschrift, 26, 734-735.

Walker, W. A., Isselbacher, K. J., and Bloch, K. J. (1975). The role of immunization in controlling antigen uptake from the small intestine. In The Immunoglobulin A System. Edited by J. Nestecky and A. R. Lawton. Plenum: New York.

Williams, E. W. (1978). Transport of proteins by neonatal and adult rat gut. Ph. D. Thesis: University of Wales. 